\section{As mulheres conforme a administração: uma ciência para a manutenção da opressão e da exploração?}

\author{
Marília Duarte de Souza, Deise Luiza da Silva Ferraz e Janaynna de \\ Moura Ferraz
}

\section{RESUMO}

Objetivou-se analisar como os estudos hodiernos no campo das ciências administrativas, os quais possuem como objeto de análise as mulheres em relações de trabalho, explicam as desigualdades existentes entre ser homem trabalhador e ser mulher trabalhadora. Para tanto, realizamos uma exposição teórica acerca da cientificidade moderna, como também expomos os principais aspectos que permeiam a questão da opressão à mulher. A partir de um levantamento bibliométrico sobre a temática "mulher" no campo da Administração e posterior análise de aspectos qualitativos dos textos, encontramos um corpus analítico distribuído por subárea e abordagem, o que possibilitou a emersão das categorias analíticas "maternidade e cuidado do lar" e "feminilidade versus masculinidade". Concluímos que estudos acerca da temática são recentes e escassos, porém representam uma potencialidade para a luta das mulheres, visto que a pauta se legitima enquanto científica. Contudo, também representam limitação, pois a racionalidade científica impõe-se sobre o real e, até mesmo os estudos que se propõem críticos acabam, em parte, contribuindo para a naturalização da opressão.

Palavras-Chave: ciência administrativa; mulheres; opressão; emancipação.

\section{Women According to Administration: A Science for Sustaining Oppression and Exploitation?}

\section{ABSTRACT}

The objective was to analyze how modern studies in the field of administrative sciences whose object of analysis is women in labor relations explain the inequalities between being a working man and being a working woman. To this end, it was made a theoretical exposition about modern scientificity and also the main aspects that permeate the issue of oppression of women was exposed. From a bibliometric survey on the theme "woman" in the field of Administration, and subsequent analysis of qualitative aspects of the texts we found an analytical corpus distributed by subarea and approach, which $t$ made it possible the emersion of the analytical categories "motherhood and homecare" and "femininity versus masculinity". We conclude that such studies on the subject are recent and scarce, but represent a potential for women's struggle since the agenda is legitimate whilst scientific. However, they also represent a limitation, because scientific rationality imposes itself over the real, and even those articles that present themselves as critical ones end up, in part, contributing to the naturalization of this oppression.

Keywords: administrative science; women; oppression; emancipation.
Recebido em: 27/04/2020 Revisado em: 21/09/2020 Aprovado em: 11/02/2021

Check for updates

Marília Duarte de Souza (iD, Universidade Federal de Minas Gerais, Brasil

Mestra em Administração,

Universidade Federal de Minas Gerais, Brasil

mariliaduartesouza@gmail.com

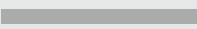

Deise Luiza da Silva Ferraz (iD,

Universidade Federal de Minas Gerais, Brasil

Doutora em Administração,

Universidade Federal do Rio Grande do Sul, Brasil

\section{deiseluizaferraz@gmail.com}

\section{Janaynna de Moura}

Ferraz (iD,

Universidade Federal do Rio Grande do Norte, Brasil

Doutora em Administração,

Universidade Federal de Minas Gerais, Brasil

jannaferraz@me.com 


\section{Introdução}

Múltiplas são as formas de apreender o real, isto é, de conhecer e transformar. Transformamos nossos modos práticos de vida em expressões teóricas e formas de consciência - artísticas, religiosas, senso comum, científicas - e cada forma de expressão tem seus modos próprios de efetivação e sua organização interna de funcionamento (Marx, 2007). Conforme apontamentos marxianos, a ciência expressa a transposição do concreto para o pensamento, e como o concreto é a síntese de múltiplas determinações e unidade do diverso, a atividade de apreender esse concreto e transpô-lo para o pensamento exige romper sua manifestação imediata e agarrá-lo pela raiz (Marx, 2013).

O caráter radical do fazer científico em uma apreensão histórica e materialista, em sua tradição e acúmulo, sustenta que a raiz da humanidade é a própria humanidade, ou seja, são as relações que os seres humanos estabelecem entre si a partir de condições históricas dadas, mas com a possibilidade de alterá-las, pois a natureza da humanidade é ser ativo de uma atividade sensível, objetiva e subjetiva ao mesmo tempo. Neste duplo aspecto, o momento preponderante é a própria existência material da vida. Conforme posto por Vaisman (2006), o pensamento tem um caráter onto-prático.

Por isso, Marx e Engels (2007, p. 41) firmam que: "a efetiva riqueza espiritual do indivíduo depende inteiramente da riqueza de suas relações reais" e assim, os autores, em uma crítica aos pensadores idealistas, informam que não se trata de explicar "a práxis partindo da ideia, mas de explicar as formações ideias a partir da práxis material” (Marx \& Engels, 2007, p. 43). Partindo da práxis estabelecida em uma sociedade de classes, as ideias dominantes são as ideias da classe dominante.

A classe que tem à sua disposição os meios de produção material dispõe também dos meios de produção espiritual, de modo que a ela estão submetidos aproximadamente ao mesmo tempo os pensamentos daqueles aos quais faltam os meios da produção espiritual. As ideias dominantes não são nada mais do que expressão ideal das relações materiais dominantes (Marx \& Engels, 2007, p. 43).

Assim, por um lado, o fazer científico que se encontra limitado à necessidade de produzir um conhecimento que colabore com a reprodução dos interesses da classe dominante, estaria impossibilitado a superação da aparência dos fenômenos, uma vez que é apenas na aparência que o interesse de uma classe se apresenta como interesse universal. Por outro lado, esse mesmo fazer tem a potencialidade de produzir conhecimentos revolucionários que contribuam com as lutas por alterações qualitativas nas condições concretas de reprodução da existência humana. No entanto, para tal, é necessário ser uma ciência capaz de revelar a essência de um objeto e assim produzir um conhecimento que expresse as relações sociais em sua concretude, demonstrando como as múltiplas determinações expressam-se no real imediato.

Uma manifestação aparente que demonstra que há elementos determinantes das desigualdades de condições para 0 livre desenvolvimento humano é a relação social existente entre mulheres e homens. As desigualdades de condições são vivenciadas na imediaticidade 
e particularidade da vida e são expressas no cinema e nas telenovelas (Macedo, 2016; Caminhas, 2019), nas pesquisas salariais, nos relatórios e nos seus números de feminicídios (UN Women, 2020). Essas expressões são indicativos de que, a despeito de todas as reivindicações realizadas pelos mais diversos movimentos de mulheres - ou feministas -, ainda reproduzimos condições reais de opressão e violência contra a mulher. Por isso, sustentamos que produzir um conhecimento que apreenda a realidade das relações sociais entre mulheres e homens pela raiz é uma das condições necessárias, embora não suficiente, para criar a possibilidade de alteração da opressão feminina.

Nos situamos mais detidamente em como a ciência administrativa tem tratado a relação entre trabalho e gênero nas últimas décadas, isto é, a produção hodierna acerca das reflexões sobre as práticas vivenciadas pela "mulher" (Cappelle \& Melo, 2010; Corrêa, Gontijo, Assis \& Carrieri; Melo, 2007; Grzybovski, Boscarin \& Migott, 2002; Machado, Gazola \& Anez, 2013; Rosa, Medeiros \& Valadão, 2012), sobretudo no que tange o mundo do trabalho e da gestão. Perante isso, a questão norteadora deste artigo é a seguinte: como os estudos hodiernos no campo das ciências administrativas que possuem como objeto de análise as mulheres em relações de trabalho explicam as desigualdades existentes entre ser homem trabalhador e ser mulher trabalhadora?

Para encontrar respostas a essa questão submetemos o corpus do conhecimento sobre a mulher produzido no campo das ciências administrativa à análise, buscando apreender o que o campo científico do tema em tela expressa, em seus aspectos quantitativos e qualitativos. Para apreender aspectos quantitativos, realizamos um levantamento bibliométrico sem corte temporal, o qual resultou em 76 artigos publicados entre os anos 1980 e 2018 em periódicos nacionais dos estratos superiores do Qualis Capes. No que se refere à apreensão de aspectos qualitativos, realizamos uma análise do conteúdo dos textos, que culminou em três tipologias e nos permitiu quantificar esse corpus, de modo a também classificá-lo qualitativamente atribuindo um grau de radicalidade diante de sua posição de naturalização do papel social da "mulher". Os trabalhos considerados como críticos problematizaram de alguma maneira um "feminino dado". Vale ressaltar que esse é um critério concernente com a tese sustentada nesta pesquisa e não uma classificação epistemológica acerca da posição dos trabalhos.

Em outras palavras, não se pretende avaliar a pertinência dos trabalhos em sua coerência interna ou comparar epistemologias, assim, trata-se de, a partir do exame do conhecimento produzido, demonstrar como bases científicas as quais reproduzem a opressão podem aparecer mesmo quando se está lutando contra ela, e isso ocorre, pois, a produção de conhecimento dentro da lógica da exploração capitalista é parcelar, subjetivista e fragmentada (Ferraz, Chaves, \& Ferraz, 2018). Além disso, cinco textos representantes das tipologias encontradas foram selecionados para uma análise em profundidade seguindo orientações da análise imanente (Chasin, 2009), de forma a visar apreender como as ciências administrativas explicam as diferenças entre as mulheres e homens. Sendo assim, tal análise nos permitiu refletir como essas explicações são mediações necessária para a manutenção das opressões. 
Para realizar a discussão proposta, o artigo é composto pela presente introdução, seguida de uma revisão teórica que busca compreender os principais aspectos que permeiam a construção da cientificidade moderna e da ciência administrativa, assim como a questão da opressão à mulher. Em seguida, temos a metodologia, análise de dados, considerações finais e referências.

\section{Conhecimento Científico Reificado e a Administração como Ciência Parcelar}

Para compreender o complexo contraditório do qual o conhecimento científico faz parte, é preciso analisá-lo de forma engendrada aos aspectos materiais determinantes postos pelo modo determinado de produção e reprodução da vida; para isso, recorremos a Mészáros (2016). Inicialmente cabe diferenciar a atividade de produção e reprodução do ser social, ou seja, a interação fundamental entre Ser Humano e Natureza mediada pelo trabalho, da atividade produtiva capitalista, ou seja, da atividade produtiva em sua forma histórica alienada.

Mészáros (2016), a partir de Marx, descreve a produção e reprodução da vida em seus elementos essenciais e universais como sendo a relação entre "homem" $(\mathrm{H})^{1}$, "natureza" $(\mathrm{N})$ e "indústria" ou "atividade produtiva" $(\mathrm{I})^{2}$. Em tal relação, na mediação de primeira ordem do metabolismo social (Figura 1) existe uma reciprocidade dialética: o "ser humano" não é apenas criador da indústria, mas também seu produto; ao alterar a natureza, altera a si mesmo; ao satisfazer suas necessidades por meio dos produtos resultantes da atividade produtiva, produz novas necessidades, ao se relacionar com os produtos da atividade de outros seres humanos se relaciona com seu gênero. Ou como está na elaboração de Marx (2004), o gênero (humano) se autoproduz objetivamente e subjetivamente por meio do trabalho como atividade humana sensível, o "ser humano" é, portanto, um ser social.

Compõe o momento dessa atividade produtiva a apreensão cognitiva da relação, ou seja, a produção de um conhecimento sobre a natureza, a humanidade e as possibilidades causais e teleológicas dessa e nessa relação. Portanto, existe também, nessa mediação de primeira ordem, um processo de produção de bens/produtos que é determinado pela produção de valores de uso, ou seja, a produção de bens/produtos na qual o fim último da produção é o de suprir necessidades humanas e, em última instância, a produção do conhecimento que está também determinada pela necessidade de produção de valores de uso.

\footnotetext{
1 Marx, como filósofo de seu tempo, utiliza o termo homem para se referir ao gênero humano, como muitos ainda fazem, mesmo decorrido mais de um século. Porém, nós substituiremos o termo "homem" por "ser humano" no decorrer do texto, respeitando apenas as citações diretas de Marx e Mészáros.

2 Observamos que Mészáros usa o termo indústria para referir-se às atividades produtivas, com essa opção, 0 autor visa frisar a indústria enquanto produto de um desenvolvimento histórico da atividade produtiva humana que não deixa de ser também uma atividade produtiva.
} 
Figura 1 - Relação Homem (H), Natureza (N) e Indústria (I)

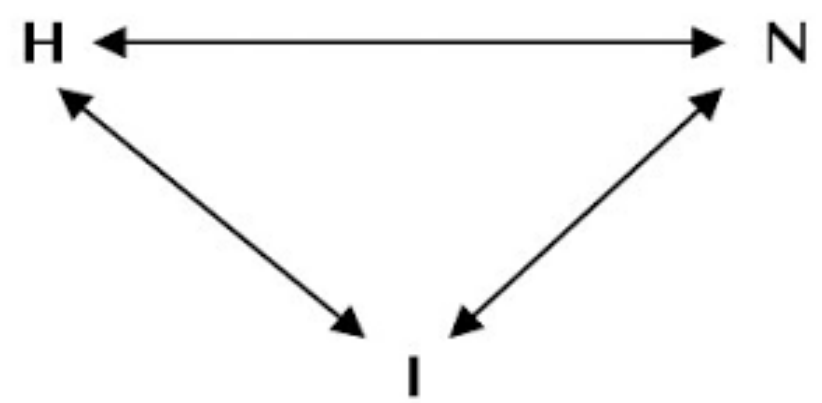

Fonte: Mészáros (2006, p. 100).

$\mathrm{Na}$ particularidade do modo de produção capitalista, no entanto, a atividade produtiva que caracteriza a produção e reprodução do ser social repõe a autoalienação do trabalho da qual a propriedade privada dos meios de produção é produto, assim como demonstrou Marx (2004) nos Manuscritos Econômicos-Filosóficos. A autoalienação no e do trabalho desenvolvida ao longo do próprio desenvolvimento humano como relação estranhada é a base concreta sob a qual desenvolve-se a propriedade privada. Assim, grupos humanos apartados dos meios de produção estão impossibilitados de (re)produzirem sua existência se não venderem a única coisa que Ihes restam: a capacidade física e espiritual apta à atividade produtiva, a saber, sua força de trabalho. Institui-se assim as bases da relação contraditória entre a classe proprietária dos meios necessários à atividade produtiva (I) e a classe de indivíduos que somente se reproduzem se alienar a outrem a capacidade produtiva (Marx, 2004).

Nesse sentido, para Mészáros (2006), a atividade produtiva essencial é subjugada a uma mediação de segunda ordem, ou seja, a possibilidade da efetivação da atividade produtiva fica subjugada a uma relação de troca entre portadores dos meios de produção e vendedores de força de trabalho, relação que não é, por si só, uma necessidade da atividade produtiva em geral, mas da atividade produtiva capitalista. Em resumo, mediação de segunda ordem trata-se de uma relação entre os Proprietários dos Meios de Produção (P) e os que estão livres dessa propriedade, os vendedores da Força de Trabalho (T). O Ser humano está particularmente cindido em P e T. E, assim:

\footnotetext{
[...] as mediações de segunda ordem de $\mathrm{P}$ e $\mathrm{T}$ tomaram o lugar do "homem" $(H)$ - os conceitos de homem e humanidade podem parecer simples abstrações filosóficas para todos aqueles que não conseguem enxergar além do imediatismo direto das relações alienadas. [...]. O desaparecimento do "homem" [ser humano] desse quadro, sua supressão prática por meio das mediações de segunda ordem de P e T - (tivemos de omitir as outras mediações institucionalizadas de segunda ordem, como por exemplo, troca, dinheiro etc., em parte porque já estão implícitas em $\mathrm{P}$ e T e em parte para simplificar as inter-relações básicas, na medida do possível) - significam não só que há agora uma separação em cada elo dessas relações alienadas, mas também que o trabalho pode ser considerado como simples "facto material", em lugar de ser visto como a agente humano de produção (Mészáros, 2016 p. 104).
}

A reificação da humanidade engendrada pela multiplicidade de inter-relações decorrentes da autoalienação do trabalho (Figura 2) expressa-se em todos os aspectos da sociabilidade, inclusive no campo científico, conforme pode ser observado na Figura 3. 
Figura 2 - Relação Homem (H) - Propriedade Privada (P) Trabalho Assalariado (T), Natureza Alienada (NA) e Indústria Alienada (IA)

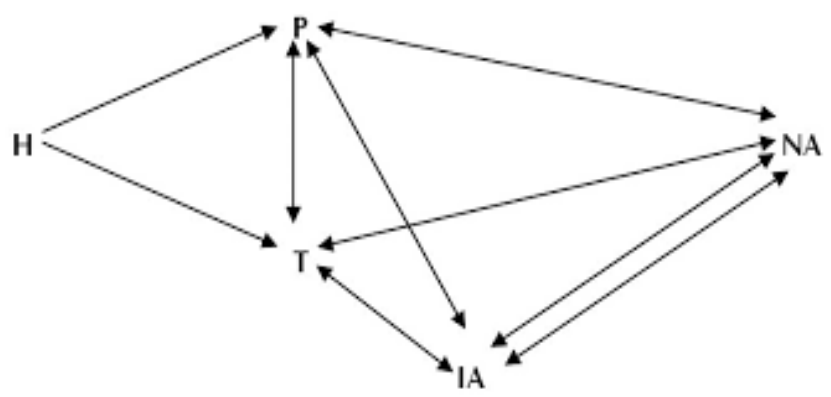

Fonte: Mészáros (2006, p. 103).

Figura 3 - Posição da Ética, da Economia Política e das Ciências Naturais, acerca das relações sociais de produção alienadas e reificadas

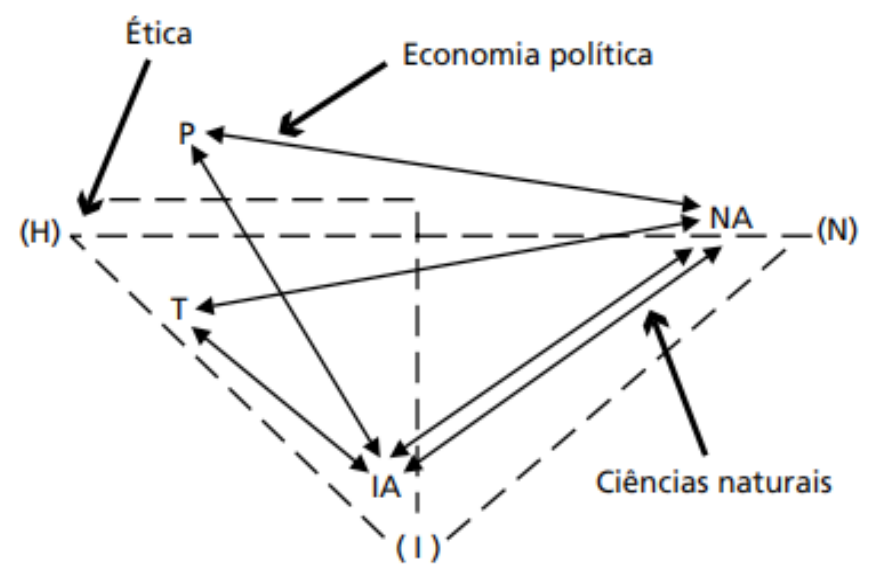

Fonte: Mészáros (2006, p. 104).

É possível perceber, por meio dessa ilustração, que os "pontos de referência centrais" da Economia Política, da Ética e das Ciências Naturais não são os mesmos e por isso, a "linguagem" de tais áreas da ciência não pode ser a mesma. Mészáros (2016) coloca que as esferas teóricas refletem a alienação e a reificação das relações sociais de produção.

No que diz respeito à Economia política, esta debruça-se sobre a tríade: $\mathrm{P}$ - NA - T e P - IA -NA. Como ela se debruça na produção de conhecimento a partir de relações alienadas, em seu horizonte não está posto a necessidade da produção de valores de uso como fim último, ou seja, a reprodução do ser humano em sua humanidade, mas sim a produção de valores de troca. A economia política pôde assim assumir a propriedade privada dos meios de produção e a apropriação do mais valor como sendo uma lei natural do desenvolvimento da humanidade. Sendo assim, por meio do conhecimento científico, a subjugação da mediação de primeira ordem (produtora de valores de uso) às mediações de segunda ordem (relações de produção produtoras de valor e mais valor) é reproduzida e naturalizada.

A ciência administrativa, objeto específico de nosso estudo, decorre desse processo de fragmentação na produção de conhecimento. Ao tomar o desdobramento da parcialização da Economia Política, entendemos como 
a disciplinaridade contribuiu para perpetuar a reificação das relações de produção capitalista. Se aos economistas políticos interessava compreender a relação entre a produção da riqueza nacional enquanto um duplo movimento de produção de valor e processo de trabalho (Adam Smith, Karl Marx, dentre outros são exemplos desse grupo tidos como clássicos da economia política), a instituição da Economia desprovida da Política desloca a razão do/a pesquisador/a para o processo de circulação e controle da riqueza produzida (a chamada escola neoclássica). Logo, o processo de trabalho detém-se em disciplinas como a Administração, que se constitui como ciência que investiga o processo de produção sem observar o processo de valorização (Ferraz \& Ferraz, 2018).

Assim, a Administração consegue avançar na produção do conhecimento sobre (a gestão do) processo de trabalho, se isentando de investigar as contradições inerentes à subsunção deste mesmo processo, subsumido a um processo de valorização do valor, ou seja, partindo da relação do $\mathrm{T}$ e do $\mathrm{P}$ com a IA. Logo, o processo de trabalho apenas se dá se for submetido à exploração do trabalho. Temos com isso que as relações de exploração subjazem sob uma aparente cientificidade que oculta, reifica e aliena, advogando, assim, por uma verdade imutável: a inevitabilidade do capital ${ }^{3}$.

Deste modo, tem-se que a lei de acumulação capitalista, uma lei determinada por uma prática histórica, aparece enquanto lei de produção e reprodução universal da humanidade. Como explicita Marx (2013), a lei de acumulação capitalista é a expressão da necessidade da produção de mais-valor. Ao iniciar sua discussão sobre o mais-valor, Marx (2013, p. 305) denomina como "tempo de trabalho necessário", ou seja, o tempo em que o trabalhador produz apenas para a sua reprodução enquanto força de trabalho, o que the é pago em forma de salário. Toda produção de valor que excede ao valor da força de trabalho é produção de mais-valor. Existem especificidades na produção e realização do mais-valor (discussão trabalho produtivo e improdutivo) que não serão aprofundadas no presente texto. Por ora, destaca-se que, na medida em que o modo de produção capitalista se desenvolve e se complexifica, torna-se cada vez mais necessário, para P, o encurtamento do "tempo de trabalho necessário", a fim de aumentar a produção (e apropriação) do mais-valor. Assim, se torna de fundamental importância os meios de planejamento e de um controle cada vez maior do processo de trabalho. Eis a base sobre a qual está fundado o conhecimento administrativo: atender as necessidades do capital de intensificação e expansão da produção do mais-valor e de sua realização. Posto de outro modo, importa à ciência administrativa a relação alienada entre T-IA, para a qual todo processo de trabalho não é observado como processo de valorização.

Nesse sentido, quanto à necessidade da função do/a Administrador/a na produção e reprodução do capital, Marx coloca:

$3 \mathrm{E}$ isso está posto inclusive para vários paradigmas que, embora rompam com o pressuposto das verdades universais, mantém a inevitabilidade do capital como verdade universal, sobretudo quando confessam não se ocuparem com a necessidade de superação das relações capitalistas de produção. 
Se a direção capitalista é dúplice em seu conteúdo, em razão da duplicidade do próprio processo de produção a ser dirigido - que é, por um lado, processo social de trabalho para a produção de um produto e, por outro, processo de valorização do capital -, ela é despótica em sua forma. Com o desenvolvimento da cooperação em maior escala, esse despotismo desenvolve suas formas próprias. Assim como o capitalista é inicialmente libertado do trabalho manual tão logo seu capital tenha atingido aquela grandeza mínima com a qual tem início a produção verdadeiramente capitalista, agora ele transfere a função de supervisão direta e contínua dos trabalhadores individuais e dos grupos de trabalhadores a uma espécie particular de assalariados. Do mesmo modo que um exército necessita de oficiais militares, uma massa de trabalhadores que coopera sob o comando do mesmo capital necessita de oficiais (dirigentes, gerentes) e suboficiais (capatazes, foremen, overlookers, contre-maîtres) industriais que exerçam o comando durante o processo de trabalho em nome do capital. O trabalho de supervisão torna-se sua função fixa e exclusiva (Marx, 2013, p. 407)

A função de controle sobre o processo de produção é, segundo Marx (2013), transferida para uma parcela de trabalhadores específicos (Paço-Cunha, 2018) e a função de gestor do processo de trabalho será trabalho produtivo ou improdutivo para o capital, a depender de qual processo concreto está controlando: será trabalhador produtivo se o processo está sob o comando do capital produtivo, será trabalhador improdutivo se gerir o processo sob o comando do capital mercantil (Cotrim, 2012). Mas, a despeito de ser trabalho produtivo ou improdutivo, para sua realização conforme as necessidades do processo de valorização e para a produção de uma força de trabalho capaz de executá-lo, fez-se (e faz-se) necessário conhecer as especificidades decorrentes da produção, da circulação e do consumo de mercadorias e das relações de produção, assim, põe-se e repõe-se a necessidade de uma ciência para tal controle: a ciência administrativa. O conhecimento científico pautado pelo critério de cientificidade moderna, caracterizado, sobretudo, pela ausência da totalidade, propiciada pela forma alienada, fragmentada e parcelar se expressa na Figura 3. Na Ciência Administrativa, a fragmentação torna-se perceptível, pois além de apreender o processo de produção apenas como processo de trabalho produtor de valores de uso (isentando-se de discutir o processo de valorização), ainda esquarteja o movimento, construindo fronteiras artificiais que se expressam sobre as rubricas de: Estudos Organizacionais, Gestão de Pessoas, Finanças, Logística, Operações, Marketing, Empreendedorismo, Estratégia Organizacional, dentre outras. Cada uma delas analisa um momento específico do processo geral de produção enquanto processo de trabalho apenas (Ferraz \& Ferraz, 2018).

Em um aspecto de sua manifestação, essa fragmentação é resultado direto da especialização de determinados aspectos da produção, de forma que se possa alcançar o objetivo posto à Administração: o maior controle dos fatores objetivos e subjetivos do processo de trabalho. Em outro, o fenômeno de fragmentação da Ciência Administrativa permite a não-compreensão do processo em sua totalidade e assim, a relação de exploração existente entre capital-trabalho aparece como algo espontâneo, portanto, inevitável. O ser social e a atividade produtiva permanecem reificadas e a falta da compreensão da totalidade da realidade social imprime aos fenômenos sociais uma aparente relação de naturalidade. 
Assim, como uma ciência construída sobre as bases do padrão gnosiológico da cientificidade moderna (Lukács, 2010), a Ciência Administrativa tende a produzir um conhecimento que reforça os padrões sociais que estão intrinsecamente ligados à produção e reprodução do capital. Importante salientar que dentre esses padrões sociais (re)produzidos com reprodução da exploração capitalista - nem antes e nem depois, mas em um mesmo processo - há as diversas relações de opressão.

Cabe aqui uma reflexão: se o objetivo da ciência moderna, em especial da Ciência Administrativa, consiste em conhecer sem questionar o processo de valorização, ou seja, consiste em conhecer para atender aos interesses do capital, teria como ser ela um conhecimento científico não ideológico, conforme muitos apologéticos do capital desejam? Ou apenas o conhecimento que questiona a manutenção do sistema social pautado na reificação do ser humano seria ideológico?

É a luz de tal discussão que questionamos a suposta "verdade científica" construída a partir do modelo de cientificidade que assume gnosiologicamente as mediações de segunda ordem como relações necessariamente humanas, ou seja, naturalizando-as a fim de eternizá-las. Tal questionamento é uma necessidade posta pelas práticas das relações concretas vividas, sobretudo ao que toca às vivências dos seres humanos que conjugam relações de exploração e opressão, como demonstraram as mulheres intelectuais como Montenegro (1981), Saffioti (2001), Toledo (2003) Cotrim e Cotrim (2020). Sobre esse questionamento, refletimos a seguir.

\section{Relações de Opressão como Necessidade Histórica do e no Capital}

O capitalismo não instaurou a exploração de um grupo social por outro, tampouco instaurou a opressão da mulher pelo homem, porém isso não significa que sempre houve e sempre haverá relações de exploração e de opressão; tampouco significa que as formas de exploração e de opressão eram as mesmas durante toda a existência da humanidade. Ao contrário, por haver diferenças nas formas de exploração e opressão; pode-se afirmar que mudanças qualitativas nas relações sociais são possíveis. Isso é o que mostram os estudos das brasileiras Montenegro (1981), Saffioti (2001), Toledo (2003) e Cotrim e Cotrim (2020), dentre outras pesquisadoras feministas nacionais e internacionais. Porém, optamos por trabalhar apenas a produção intelectual brasileira uma vez que o objeto em tela é a ciência nacional.

Importante salientar que as autoras supracitadas, ao estudarem as relações entre homens e mulheres no desenvolvimento histórico da humanidade, não abstraem as determinações de classe, pois aprenderam que as opressões à mulher assumem distintas formas e intensidades em conformidade ao lugar que as mulheres se encontram na estrutura social e nos nichos da classe trabalhadora. No Brasil, por exemplo, a raça coloca a mulher negra em uma condição de maior possibilidade de opressão que a mulher branca (Nascimento, Oliveira, Teixeira e Carrieri, 2015) ainda que ambas "ofereçam" à exploração uma mesma capacidade técnicas 
em conformidade com a divisão técnica do trabalho, conforme apontam os dados de estudos como "A feminização do mundo do trabalho: entre emancipação e precarização" de Nogueira (2004) e relatórios publicados como "Diferenciais Salariais por Raça e Gênero para Formados em Escolas Públicas ou Privadas", realizado pelo Instituto Insper (2020) e "Tempo de Cuidar" realizado pela Oxfam (2020).

Se, por um lado, a opressão da mulher não tem sua origem em uma determinada natureza do ser mulher e tampouco é um fenômeno nascido com a sociedade capitalista, por outro, neste modo de produção ela ganha contornos específicos em conformidade com relações sociais subsumidas ao processo de exploração Capital-Trabalho. Nesse ponto retomamos a explicação de Mészáros (2003) a respeito da cisão do ser social em T e P, visando ampliar sua elaboração a fim de situar a opressão como uma forma de relação social necessária ao modo capitalista de produção.

Nessa cisão também se observa o desenvolvimento de uma relação de desigualdade do ser humano que se expressa como particularidades complexas em T e P (Figura 04). A atividade produtiva, mediação de primeira ordem, não necessita das diferenças entre homem e mulher. A atividade produtiva, essa relação simbiótica entre seres humanos e natureza, não impõe à mulher uma condição de inferioridade social, tampouco impõe a responsabilidade da maternidade - ainda que imponha o tempo gestacional.

A mediação de segunda ordem, a propriedade privada dos meios de produção, conforme corrobora Cotrim e Cotrim (2020), criou as condições objetivas para forjar uma nova mulher, engendrada a partir das condições do ser mulher já existente. O novo é gestado no velho. A propriedade privada dos meios de produção faz ruir o modo de produção em que a reprodução do grupo social - representado na família - ocorre no interior da família segundo uma organização patriarcal; logo, não se ignora que nas relações sociais que produziram o capitalismo a mulher já se encontrava sob um determinado jugo do homem. A propriedade privada dos meios de produção, ao lançar para fora da unidade familiar (e para dentro do processo de valorização do valor) a produção dos meios necessários à reprodução da vida no seio de uma sociedade patriarcal, engendrou as bases de uma nova submissão da mulher ao Ihe incumbir a tarefa social de reprodução da mercadoria força de trabalho; tarefa essa que não foi imediatamente e em sua totalidade submetida ao processo de valorização. Com o desenvolvimento do capitalismo, observa-se que várias atividades diretamente vinculadas à reprodução da força de trabalho foram sendo - e serão - apropriadas enquanto atividades produtivas para o capital. Exemplo disso são as esferas da educação e, assim, não é coincidência que as ditas "atividades do cuidado", quando exploradas capitalisticamente, expressam a divisão sexual do trabalho.

Assim, a propriedade privada dos meios de produção, enquanto produto histórico do trabalho alienado, constitui-se no interior de condições objetivas específicas de relações de opressão da mulher (o patriarcado feudal, fundado na produção de bens no interior da unidade familiar, no qual o homem tinha plenos poderes de comando). Ao mesmo tempo, supera tais condições objetivas e engendra novas condições objetivas (fundando a produção de mercadorias fora da unidade familiar) que necessitam da 
manutenção da opressão, em especial, devido à necessidade de atividades vinculadas à reprodução da força de trabalho, ainda que com novas formas e contornos, tem-se um patriarcado especificamente capitalista. A Figura 4 resume esquematicamente esse desenvolvimento.

Figura 4 - Expressão das Relações de Gênero nas Mediações de Primeira e Segunda Ordem

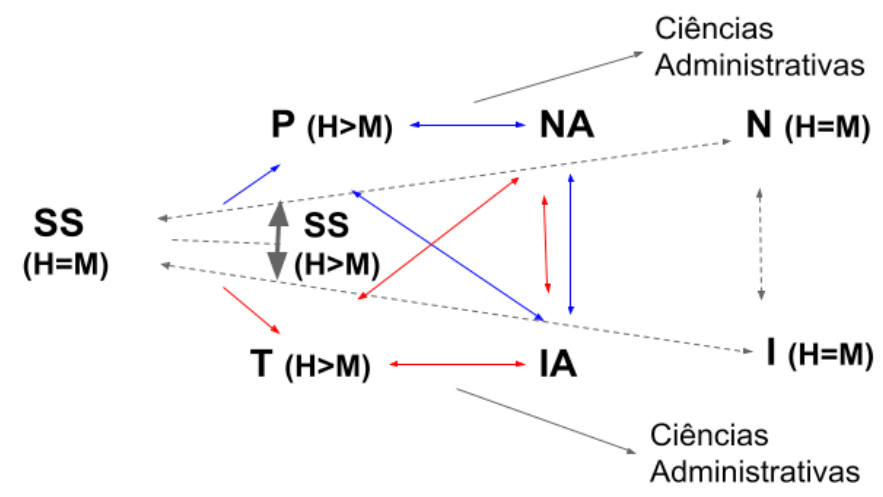

Fonte: Adaptado de Ferraz (2012)

Nota: Onde: $S S(H=M)$ - Ser Humano sem desigualdade entre homens e mulheres; $S S(H>M)$, ser humano alienado de sua generidade, há desigualdades entre homens e mulheres.

A alienação do ser humano de sua generidade desdobra-se também na desigualdade entre homens e mulheres - desde a divisão sexual do trabalho até a ideia do que seria um trabalho masculino ou feminino -, pois a alienação do ser humano de sua humanidade é também a alienação de cada membro da espécie do outro. Por estarmos impossibilitados concretamente de nos reconhecermos como a unidade do diverso, é que podemos produzir o diverso como desigual.

Essa desigualdade entre homens e mulheres não está restrita apenas a classe trabalhadora, posto que a alienação é social e não apenas "privilégio" das trabalhadoras e trabalhadores; a desigualdade entre homens e mulheres se faz presente também na classe burguesa (Toledo, 2003). Porém, assim como as condições de vida dos membros da classe trabalhadora se distinguem das condições de vida dos membros da classe burguesa, as opressões também se manifestam conforme a particularidade de cada classe e, neste caso, asseveradas pela exploração de uma classe pela outra.

Nas relações de opressão faz diferença o indivíduo ser homem ou ser mulher. Na relação de exploração faz-se necessárias relações de opressão (da mulher, do povo preto, dos LGBTQIA+, etc.) a medida em que ela é mecanismo para o aumento da exploração. No caso da mulher, sua opressão é condição para a reprodução da classe trabalhadora enquanto classe de trabalhadores e trabalhadoras. A concorrência intraclasse trabalhadora possibilita maior grau de exploração da força de trabalho feminina e das demais forças de trabalho as quais sofrem um processo de opressão, conforme discute Saffioti (2001), e também do próprio homem da classe trabalhadora. É nesse sentido que a opressão da mulher intraclasse trabalhadora é importante para a classe capitalista, assim como lutar contra tal opressão compõe o movimento de resistência de e para toda a classe trabalhadora e não somente expressa a resistência da mulher. 
Assim, nesse complexo de complexos, compreende-se porque a luta da mulher da classe trabalhadora é antes uma luta contra a classe burguesa que passa necessariamente pela luta contra a opressão intraclasse trabalhadora do que uma luta contra a "classe" de homens, conforme advogam algumas autoras do feminismo radical (Silva, 2008). Somente a libertação da mulher trabalhadora e do homem trabalhador da autoalienação do trabalho liberta o ser humano das condições de exploração e opressão existentes, por superar a cisão colocada pela propriedade privada dos meios de produção que constituíram as novas bases concretas para novas formas de opressão. Ou, como diria Marx (2004, p. 89), na emancipação da classe trabalhadora está "encerrada a [emancipação] humana universal. Mas esta [última] está aí encerrada porque a opressão humana inteira está envolvida na relação do trabalhador com a produção, e todas as relações de servidão são apenas modificações e consequências dessa relação". Opressão e exploração, desse modo, se engendram e a primeira tem sido necessariamente demandada como base por onde se move graus distintos de exploração que é legitimada culturalmente pelo "sempre foi assim e sempre será", afinal "a mulher é naturalmente mais sensível por ser mãe" ou ainda "para ser uma mulher completa, precisa ser mãe".

A preponderância de uma explicação biológica sobre as relações sociais femininas foi e é, em grande medida, reforçada pela cientificidade moderna. Para Saffioti (2001, p. 23) a ciência e o uso que dela se faz traz a marca da manipulação das mulheres e "deste processo de nutrir cotidianamente os preconceitos que permitem uma maior dominação-exploração dos elementos femininos". Considerando essas colocações, a produção do conhecimento sobre as questões das relações de opressão, em específico aqui, da mulher, no campo científico das Ciências Administrativas, tem lugar privilegiado, pois é essa área do saber que tem como centralidade a relação de quem produz com a produção [T $(H M)$ - IA], ou seja, as relações de exploração que determinam as relações de opressão e são por elas sobredeterminadas.

Deste modo, retornamos à nossa pergunta: como os estudos hodiernos no campo das ciências administrativas que possuem como objeto de análise as mulheres em relações de trabalho explicam as desigualdades existentes entre ser homem trabalhador e ser mulher trabalhadora? Algumas respostas foram possíveis após análise dos dados que foram coletados a partir do percurso exposto a seguir.

\section{Dercurso Metodológico e Análise}

Pode-se caracterizar a abordagem desta pesquisa como materialista histórica, por isso, a exposição do resultado da pesquisa apresenta aspectos quantitativos e qualitativos do real em tela: a produção científica sobre o tema. No materialismo histórico o pensamento não atribui às práticas sociais nenhum dos dois aspectos; é o próprio fenômeno que existe enquanto manifestação quantitativa e qualitativa. Essa é a razão pela qual é possível nos valermos de técnicas de análise utilizadas por pesquisas apriorística e gnosiologicamente classificadas quanto à sua natureza. 
Para esta pesquisa, no caso da apreensão do aspecto quantitativo do fenômeno, recorremos à análise estatística descritiva, pois por meio dela acessamos o campo de estudo rumo aos aspectos qualitativos que foram apreendidos por meio de uma análise de conteúdo, adaptada de Graneheim e Lundman (2004), respeitando os princípios da análise imanente, que pode ser diferenciada da outra por ir além do conteúdo semântico, pois "revela também, de forma indireta, a realidade mesma apreendida pelo autor, os seus acertos, enganos etc., configurando o embate dos homens entre si, que impulsiona o processo de conhecimento" (Costa, 2009, p. 32).

Nosso percurso metodológico começou com um levantamento bibliométrico, visando mapear a produtividade no ambiente científico por meio da análise de fontes bibliográficas definidas para que se possa identificar padrões, pontos críticos, contrapontos, tendências (Arksey \& O'Malley, 2005; Oliveira, Barbosa, Rezende e Albuquerque et al., 2013). A operacionalização seguiu os seguintes passos:

i. Foram selecionadas para a coleta de dados as revistas classificadas como alto impacto (Qualis-CAPES A1, A2, B1) para a produção nacional da Administração; não foram encontradas revistas nacionais de Administração classificadas como A1. Nos certificamos que todas as revistas possuem site próprio e disponibilizam o download dos artigos gratuitamente. Esse procedimento ocorreu em fevereiro de 2019.

ii. Critérios da busca dos artigos nos sites das revistas: a) não foi delimitado o período da busca, sendo considerado, assim, toda a base de dados desses periódicos. b) As palavras-chave buscadas foram: "mulheres", "mulher", "feminino", "feminismo" e "gênero", nos campos "Título" e "Palavras-chave do artigo", termos e variações que expressam o objeto que seria investigado pelos artigos buscados ${ }^{4}$.

iii. Após realizar a busca em todas as revistas foram encontrados 76 artigos que compuseram nosso corpus analítico que foi inicialmente submetido a uma descrição quantitativa e depois a uma análise qualitativa.

Quanto à descrição quantitativa destacamos que ao considerarmos a distribuição dos Qualis das revistas em relação à quantidade de trabalhos publicados, podemos verificar, conforme mostra Tabela 1, que 60,53\% dos artigos se concentram nos periódicos A2.

4 Apesar de a metodologia de levantamento bibliométrico apresentada neste trabalho se aproximar de trabalhos já publicados, como o de Souza, Corvino e Lopes (2013) encontramos algumas divergências, uma vez que, por motivos explicitado neste item, realizamos a busca apenas nos campos "título" e "palavras-chave". 
Tabela 1 - Distribuição dos Artigos por Qualis e Revistas

\begin{tabular}{clc}
\hline Qualis & Revista & Quantidade \\
\hline & Cadernos Ebape BR & 11 \\
A2 & O\&S. Organizações \& Sociedade & 7 \\
$(46$ artigos) & RAC - Revista de Administração Contemporânea & 9 \\
$60,53 \%$ & RAE - Revista de Administração de Empresas & 7 \\
& RAP - Revista de Administração Pública & 12 \\
\hline & Organizações em Contexto & 5 \\
B1 & RAM - Revista de Administração Mackenzie & 11 \\
(30 artigos) & RCA - Revista de Ciências da Administração & 5 \\
$39,47 \%$ & REAd. Revista Eletrônica de Administração & 6 \\
& Recadm Revista Eletrônica De Ciência Administrativa & 3 \\
\hline TOTAL GERAL & & 76 \\
\hline
\end{tabular}

Fonte: Dados da Pesquisa (2019).

Ao analisar o ano de publicação podemos perceber que a primeira publicação acontece apenas em 1980. Como demonstra a Figura 5, as discussões acerca da temática são recentes, $80 \%$ dos artigos foram publicados nos últimos 12 anos, isto é, a produção de artigos envolvendo a temática "mulher" ganha força em 2007, tendo picos de 7 artigos publicados nos anos 2012 e 2013, um número não muito significante frente ao volume de produção das revistas investigadas.

Gráfico 1 - Distribuição por Ano de Publicação

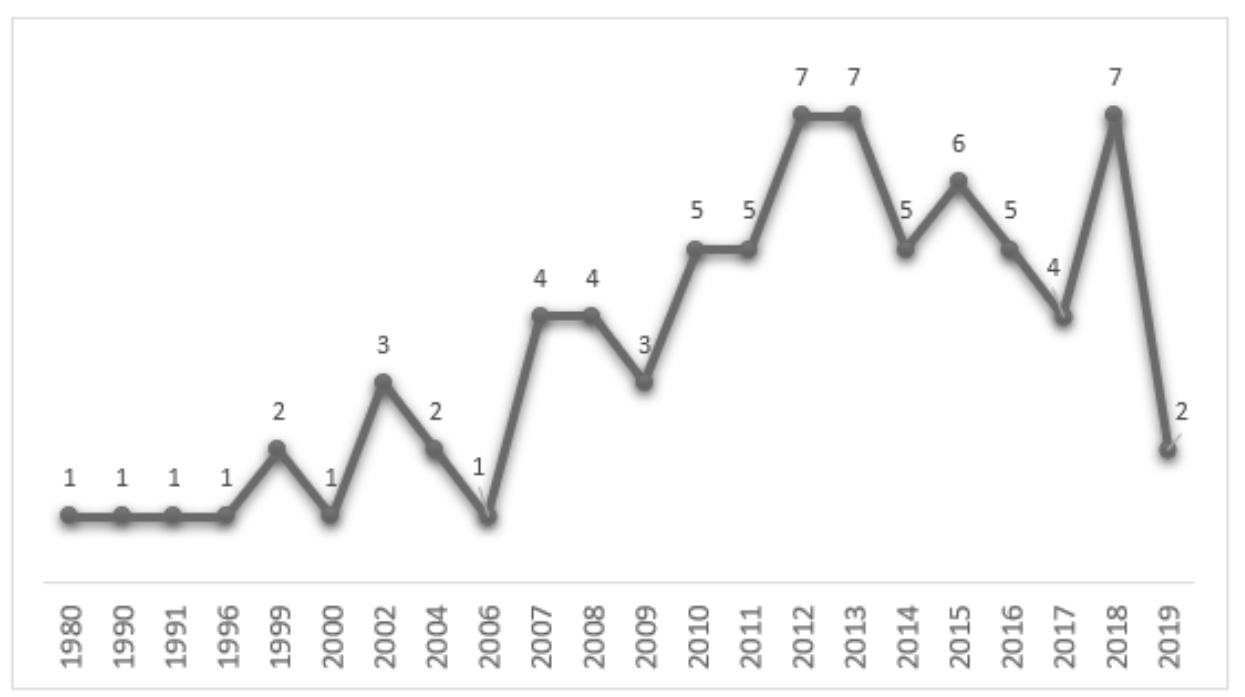

Fonte: Dados da Pesquisa (2019).

Ademais, mesmo que se convencione que a discussão da temática em tela não é a pauta da Administração, nos indagamos: é possível discutir gestão das organizações e administrativas na atualidade ignorando as particularidades das relações entre homens e mulheres? Observamos que é possível, os números aqui atestam isso, contudo, qual o corolário dessa negligência? 
Além disso, é interessante observar que se passaram 32 anos (de 1980 a 2012) para a produção de 53\% dos estudos encontrados, a outra metade da produção ocorreu nos últimos 6 anos, o que demonstra que, ainda que incipiente, entrou (mesmo que superficialmente) para a agenda de pesquisa da área. Porém seu processo de consolidação ocorre de forma desarticulada como mostra a análise das autorias dos textos.

Quanto à relação de autoria dos artigos, foram observadas algumas questões, a saber: i) não existe uma rede de autoras ${ }^{5}$ e autores engajados na discussão do presente tema; ii) ao tentar identificar um autor ou autora que pudesse apresentar-se como referência no assunto, foi percebido que a grande maioria dos autores possui apenas um único artigo publicado; assim, ganham destaques as autoras Marlene Catarina de Oliveira Melo e Mônica de Carvalho Alves Capello, contando com 4 publicações cada; iii) quanto ao gênero, 65\% são mulheres, inicialmente esse percentual parece ser um fator positivo, uma vez que pode representar uma maior visibilidade alcançada pelas mulheres na área, contudo $66 \%$ dos estudos publicados por elas possuem um caráter não crítico - será explicado mais detalhadamente a seguir - , isto é, seus artigos partem de uma perspectiva que tanto reforça quanto dissemina aspectos que são influenciadores de sua própria opressão, como veremos com a análise dos conteúdos dos textos.

Importante destacar que para obter as respostas à nossa indagação inicial, não seria possível efetuar apenas o estudo bibliométrico, pois ele não nos permitiu identificar como a ciência administrativa reproduz o ideário que corresponde à necessária manutenção das relações sociais de opressão ou não. Por isso, foi encaminhada a análise de conteúdo qualitativa dos artigos, o segundo momento da investigação, como será exposto a seguir.

O segundo momento da pesquisa, a análise de conteúdo, possibilitou aprofundar e explorar o que o levantamento bibliométrico descreveu. Essa atividade consistiu em analisar os resumos dos 76 artigos, pois conforme as regras da ABNT (2003), os resumos devem conter os principais elementos do trabalho, como objetivo, método, resultados e conclusões obtidas com o estudo. A partir dessa análise, foram sintetizadas três tipologias, de acordo com a temática que abordam, a saber: a) Relações de Trabalho, Poder e Gênero; b) Práticas Organizacionais e Relações de Gênero e c) Negócios e Empreendedorismo.

Além disso, esses artigos também foram transversalmente analisados como sendo de carácter "críticos" ou "não críticos". Foram classificados como "críticos" todos aqueles artigos que colocam questões que buscam problematizar o ideário sobre o ser mulher, a despeito de terem superado ou não a aparência do real, conforme exposto no item anterior. Temos consciência da amplitude do termo "críticos" neste texto, optamos por mantêlo para chamar a atenção que a leitura desses textos tem fraco potencial de produção de subjetividades que sejam cientes da reificação da mulher.

Vale lembrar, como foi mencionado de passagem na introdução, que não se trata de uma classificação epistemológica acerca da coerência interna do artigo (muito menos dos/as autores/as) ou de um julgamento quanto

5 Em 2018 foi criado, no Enanpad um grupo denominado COMPA - Comunidade de Mulheres Pesquisadoras em Administração. 
ao engajamento pela emancipação feminina. Crítico ou não crítico nesta pesquisa tem caráter ontológico (Lukács, 2010) que, em sentido estrito, tem a ver com tencionar o que se entende por "ser mulher" na sociedade capitalista a partir das condições objetivas de produção dessa forma de ser social.

Após realizar esta classificação, apenas 26\% dos artigos, ou seja, 20 trabalhos, puderam ser considerados críticos, sendo que 16 destes se encontram na tipologia específica "Relações de Trabalho, Poder e Gênero" e os outros 4 na "Práticas Organizacionais e Relações de Gênero". Na tipologia "Negócios e Empreendedorismo" não foi encontrado nenhum artigo que questionasse a naturalização da opressão da mulher, conforme pode ser observado na Figura 05.

Figura 5 - Tipologia e Classificação dos Artigos

\begin{tabular}{lcccc}
\hline & $\begin{array}{c}\text { Práticas organizacionais e } \\
\text { Relação de Gênero }\end{array}$ & $\begin{array}{c}\text { Relações de Trabalho, } \\
\text { Poder e Gênero }\end{array}$ & $\begin{array}{c}\text { Negócios e } \\
\text { empreendedorismo }\end{array}$ & Total Geral \\
\hline Não Crítico & 18 & 22 & 16 & 56 \\
Crítico & 4 & 16 & 0 & 20 \\
\hline Total Geral & 22 & 38 & 16 & 76 \\
\hline
\end{tabular}

Fonte: Dados da pesquisa (2019).

Percebemos que estudos, inclusive aqueles realizados por mulheres, estão naturalizando as relações opressoras e, por isso, resolvemos aprofundar a apreensão do tratamento dado pelos autores e pelas autoras ao tema. Para isso, nos encaminhamos para uma análise imanente, o último momento da análise, que embora apareça aqui como se fosse "o terceiro momento", na verdade, se espraiou durante toda a realização da pesquisa.

Selecionamos 5 artigos para a análise imanente, um crítico e um não-crítico de cada tipologia. Não foram 6 pois a tipologia "Negócios e Empreendedorismo" não tinha nenhum crítico (o que já é um indicativo). Os critérios para seleção destes trabalhos foram: a) artigo de autores ou autoras que possuíam maior produção na área, pois consideramos que as ideias expressas no texto analisado aqui tendem a estarem reproduzidas em demais textos de mesma autoria, tendo tais ideias, portanto, maior alcance de público; b) Qualis da revista, pois reconhecemos que revistas mais bem classificadas possuem maior legitimidade quanto as ideias divulgadas; e, c) ano de publicação. Os textos triados podem ser vistos na Tabela 2. 
Tabela 2 - Artigos Selecionados para Análise Final

\begin{tabular}{|c|c|c|c|}
\hline C1 - AUTORAS / AUTORES & C2 - REVISTA QUALIS & C3 - ANO & ARTIGO \\
\hline Grzybovski; Boscarin, e Migott & RAC (A2) & 2002 & Estilo Feminino de Gestão em Empresas Familiares Gaúchas \\
\hline $\begin{array}{l}\text { Corrêa; Gontijo; Assis; Carrieri } \\
\text { e Melo }\end{array}$ & $\mathrm{RAC}(\mathrm{A} 2)$ & 2007 & $\begin{array}{l}\text { Soldadinhos-de-chumbo e Bonecas: Representações } \\
\text { sociais do Masculino e Feminino em Jornais de Empresas* }\end{array}$ \\
\hline Cappelle e Melo & RAM (B1) & 2010 & $\begin{array}{l}\text { Mulheres policiais, relações de poder e de gênero na } \\
\text { Polícia Militar de Minas Gerais }\end{array}$ \\
\hline Reis; Medeiros e Valadão & EBAPE (A2) & 2012 & $\begin{array}{l}\text { Sob as sombras do discurso colonial: subalternidade e } \\
\text { configurações de gênero em uma lavanderia do interior* }\end{array}$ \\
\hline Machado, Gazola e Anez & RAM (B1) & 2013 & $\begin{array}{l}\text { Criação de empresas por mulheres: um estudo com } \\
\text { empreendedoras em Natal, Rio Grande do Norte }\end{array}$ \\
\hline
\end{tabular}

Fonte: Dados da Pesquisa (2019).

Nota: *Artigos categorizados como críticos (C). Os artigos não-críticos aparecem no texto com a sigla (NC).

Os cinco artigos foram analisados na íntegra. Primeiro, a análise de conteúdo nos apontou dois temas hegemônicos nas discussões sobre as mulheres e o mundo do trabalho e da gestão: "Maternidade e Cuidado do Lar" e "Feminilidade versus Masculinidade." E depois a análise imanente nos permitiu tencionar a naturalização do ser mulher nos artigos produzidos nas ciências administrativas.

\section{Análise em profundidade: A Ciência que} Naturaliza a Opressão de Gênero

\section{Feminilidade versus masculinidade}

Dentre os temas recorrentes encontrados nos estudos, destacamos como as diferenças entre o ser mulher e o ser homem na sociedade atual são apresentadas nos textos.

A pesquisa de Machado, Gazola e Anez (NC) (2013, p. 182) relatou que a teoria indica que uma das dificuldades encontradas pelas mulheres empreendedoras está relacionada à cultura, sobretudo naquela cuja visão preponderante é a compreensão "da mulher como dócil, frágil e desprovida de capacidade de atuar em uma sociedade comercial". Como esses elementos não apareceram entre os dados de pesquisas, os autores perderam a oportunidade de problematizar tal afirmação teórica - não houve, nem sequer, o questionamento sobre o que significa "capacidade para atuar em sociedade comercial". Discursivamente, abre-se a possibilidade, portanto, de acreditar que na cultura local de Natal (Rio Grande do Norte) não há uma imagem "da mulher como dócil, frágil [...]". Porém, a ausência do questionamento teórico demonstra que tal particularidade regional não invalida os aspectos de feminilidade atribuídos à mulher pela teoria, o que deixa intacto o solo para a perpetuação da ideia de que a mulher - com exceção das potiguares - podem ser "desprovidas de capacidade de atuar em uma sociedade comercial". 
As características de sensibilidade, propensão para o cuidado, paciência, humildade, dentre outras atribuídas às mulheres são utilizadas para associar a elas profissões relacionadas à educação, artes e cuidado, e não à gestão, a qual é associada a características de autoconfiança, poder e habilidades de segurança postas como naturais do ser homem e não do ser mulher. A menor quantidade de mulheres no campo da administração, portanto, também é justificada por essa diferença dicotômica entre as qualidades do componente feminino e masculino.

Por sua vez, Grzybovski Boscarin e Migott (NC) (2002, p. 191) sustentam que as mulheres têm características particulares nas organizações de aprendizagem, pois elas são flexíveis e humildes para se adaptar e aceitar situações de desmotivação, pacientes para começar de baixo e aprender com modéstia. Colocam ainda que tendem a exercer uma liderança mais democrática ao passo que os homens têm um estilo mais diretivo.

Nota-se como é posta, mesmo que em algumas vezes de forma sutil, a inferioridade intelectual da mulher. Os estudos enfatizam (sem problematizar) que a maioria dos cargos de chefia ou de grande relevância são ocupados majoritariamente por homens. Eles sugerem que a "falta de aspiração" de mulheres a cargos de direção ou presidentes de conselho se deve às áreas em que atuam: relações públicas, recursos humanos e comunicações, áreas em que na maioria das vezes não são lócus naturais para a escolha dos presidentes.

Percebe-se que o obstáculo ao acesso aos cargos de chefia se deve, portanto, às vontades das mulheres que escolheram determinadas profissões e não outras em virtude de suas qualidades "naturalmente" femininas. No entanto, essa suposta inferioridade intelectual que foi produzida durante os últimos séculos em função, inclusive, da proibição da mulher frequentar os bancos escolares ou estudarem determinadas disciplinas e cursarem o ensino superior é a base concreta que rebaixa o valor da força de trabalho da mulher. A mulher acaba sendo induzida a atuar em determinadas profissões e não outras, qualificando menos a sua força de trabalho e, por isso, vende sua força de trabalho por um valor menor a um capitalista ou ingressa em setores econômicos que se apropriam de uma menor taxa média de lucro quando empreendem.

Algo parecido ocorre com a naturalização do empreendedorismo, como pode ser visto no artigo de Grzybovski, Boscarin e Migott (2002), em que as autoras colocam que o percentual de mulheres empreendedoras era bem menor que o de homens empreendedores, e ainda, que o processo sucessório está historicamente relacionado à uma figura masculina, sem problematizar tais questões.

Grzybovski, Boscarin e Migott (2002) também analisam o processo sucessório em empresas familiares e apontam que na grande maioria dos casos são homens que assumem tal responsabilidade e, quando mulheres assumem, costumam utilizar "recursos do gênero masculino" para obter sucesso na gestão. Interessante observar que os estudos mostram que mesmo quando as mulheres ocupam cargos de gestão ou posição de poder nas organizações, elas são masculinizadas para justificar o fato de "darem conta do recado". Ao assumirem uma posição de poder elas precisam 
apresentar atitudes de "masculinidade", reproduzindo o "modelo masculino", para que possam ser reconhecidas e respeitadas ao ocupar tal posição, como afirmam Capelle e Melo (2010, p. 15). Para que assumam postura de liderança, requerida nos postos de gestão, elas também "abandonam seus estilos femininos nesses cargos e atuam de modo mais autocrático".

Ou seja, mesmo enquanto mulheres profissionais que se destacam, a competência delas não é ligada às suas qualidades, mas sim à sua "capacidade de se comportar enquanto homem". O estudo de Capelle e Melo (NC) (2010) abrangeu as Policiais Militares, que apontou que para conquistarem posições de destaque ou executarem atividades ligadas ao operacional, as policiais têm que adotar posturas "masculinizadas", tais como enfrentar "bandidos como homens". As autoras destacam ainda que, até na rádio da Polícia Militar não se costuma utilizar a voz feminina, uma vez que a "credibilidade" da informação é dada à voz masculina.

A questão da "feminilidade versus masculinidade" também é observada no artigo de Corrêa et al. (C) (2007). Apesar de tecer críticas quanto à divisão dos papéis sociais de homens e mulheres nos jornais internos de circulação de empresas, Corrêa et al. (2007) naturalizam diversos aspectos relacionados ao "ser homem" e "ser mulher", por exemplo. Por um lado, ao colocarem que o jornal "Vênus" trata apenas de assuntos "de interesse das mulheres" ou "tipicamente femininos" relacionando-os à culinária, beleza, família, afeto, entre outros, os autores acabam tornando aspectos como a maternidade e cuidado do ambiente doméstico como "natural" das mulheres, além de naturalizar características como sensibilidade, amorosidade e fragilidade como "tipicamente femininas". Por outro lado, quando colocam que no jornal "Marte" os ícones são sempre homens ou mulheres com trajes "tipicamente masculinos", os autores naturalizam aspectos relacionados ao "masculino".

O que não é apresentado nos artigos é uma reflexão sobre a origem dessas características de feminilidade e masculinidade, características que são impostas a ambos, como lembra Saffioti (2001, p. 8): "A identidade social da mulher, assim como a do homem, é construída através da atribuição de distintos papéis, que a sociedade espera ver cumpridos pelas diferentes categorias de sexo". A não problematização da produção dessas características de masculinidade e feminilidade ignora inclusive que, mesmo os homens, supostamente possuidores das qualidades necessárias ao sucesso no mundo dos negócios, não o têm naturalmente.

Caso as relações de poder na sociedade fossem determinadas por características naturais, o que justificaria um homem ser CEO e outro mecânico? Ambos não estão naturalmente aptos para serem CEO? Não queremos com essa indagação refutar que há desigualdades entre homens e mulheres, mas chamar a atenção que elas não são determinadas pela natureza biológica de ser ou não um indivíduo portador da combinação cromossômica XX ou XY.

Estamos salientando como as características de sensibilidade, cuidado, fragilidade, dentre outras, não são naturais das mulheres, mas sim produções que se alteram no decorrer da história e em diferentes sociedades (Toledo, 2003; Saffioti, 2001; Montenegro, 1981; Cotrim \& Cotrim, 2020). No entanto, colocá-las como naturais, permite muitas vezes "justificar" a suposta 
inferioridade das mulheres e a "menor habilidade" de cumprimento de determinadas funções, como pode ser percebido no conteúdo dos estudos analisados. Portanto, foi possível perceber o quanto o senso comum, que tipifica as práticas sociais como femininas ou masculinas, é naturalizado na ciência administrativa.

A ciência, diferente do que apregoava o iluminismo, não traz luz ao saber comum, traz luz a um conhecimento parcial construído a partir da vida imediata. A Ciência Administrativa, no que tange ao estereótipo dual e superficial da feminilidade e masculinidade, ao invés de problematizá-lo, reforça-o. Isso foi feito tanto por meio do uso de bases teóricas que permitiram o suporte da argumentação que colocam a mulher em condição natural de desigualdade perante o homem, como por meio da não problematização de tais questões, de forma que acabam propagando e reforçando a naturalização das características relacionadas ao "ser homem" e "ser mulher" e consequente utilização dessas para "justificar" o lugar social de inferioridade da mulher.

Esse processo de naturalização da feminilidade fica mais evidente quando o real se impõe aos pesquisadores e pesquisadoras. Nos estudos analisados, um ponto sempre se coloca como dificuldade para a mulher se qualificar ou se dedicar à carreira: as responsabilidades maternas. Sobre esse ponto do ser mulher sob a sociabilidade do capital é que nos deteremos a seguir.

\section{Maternidade e cuidado da casa}

Além das diferenças colocadas como "naturais", entre ser homem e ser mulher que foram apresentadas em todos os artigos analisados e demonstradas no tópico acima, outro assunto recorrente foi a questão do papel da mulher no espaço doméstico.

Um aspecto que foi colocado por todos os estudos foi a questão da "dupla-jornada", do cuidado do ambiente doméstico e da família. Conforme discutido no tópico "Relações de Opressão como Necessidade Histórica do e no Capital" o cuidado da casa e dos descendentes não constitui dever ou habilidade biológica das mulheres. No entanto, os textos analisados apresentam a divisão sexual do trabalho e o "dever" de reprodução do espaço privado imposto às mulheres em um momento histórico e social específico como algo natural e geral de toda a história da humanidade.

Vender a força de trabalho é exposto nas pesquisas analisadas como algo que ocupa um lugar secundário na vida das mulheres. Em primeiro lugar, para a mulher, está seu "dever" no espaço doméstico. Machado, Gazola e Anez (2013, p. 5), por exemplo, ao analisarem os motivos e as dificuldades das mulheres no desenvolvimento de novos negócios, destacam a obstáculos de ascensão no mercado, aliada à questão da flexibilidade de horário, porque as mulheres têm que "conciliar o trabalho às exigências do lar e da família" (Grzybovski, Boscarin, \& Migott, 2002, p. 9). Por sua vez, ao analisar a ocupação de cargos de direção ou presidência, afirmam que os homens estão mais disponíveis para assumir tamanha responsabilidade, pois "não possuem compromisso de maternidade, criação de filhos e administração da casa". 
Não discordamos desse diagnóstico dos pesquisadores e pesquisadoras. O fato de a mulher ocupar-se mais com essas "atividades domésticas" do que os homens é algo vivido cotidianamente por quase todas as mulheres. Discordamos da aceitação não reflexiva desse diagnóstico. Assim, no que tange à maternidade, a análise dos artigos nos mostrou que o cuidado e socialização dos filhos se tornou um papel tão naturalizado, que muitas vezes as próprias mulheres pesquisadoras reproduzem o que deveriam explicar. Sendo assim, conforme destacado, como separar a maternidade da mulher? Nesse sentido, olhar do mercado de trabalho na ótica das mulheres implica observar diversas outras atividades, uma vez que, além de fazer parte dos espaços produtivos públicos, à mulher compete outras atribuições sociais voltadas para a manutenção da espécie (Cappellin, 1995, como citado em Capelle \& Melo, 2010, p. 79).

Trata-se de uma perspectiva romantizada que impossibilita a separação entre mulher e maternidade. A capacidade biológica que existe no ser mulher consiste na reprodução biológica da espécie, que "por um acaso" também não cabe somente a ela e necessita tanto do homem quanto da mulher para ser de fato efetivada. $O$ fato de que, para homem esse ato dure alguns instantes, enquanto para a mulher pode durar até nove meses, não altera em nada a questão. A mulher, portanto, nasce com a capacidade biológica de carregar no ventre durante o período da gestação, mas não com um "espírito materno" para criação e educação dos filhos e filhas. Esse sentimento social produzido nos últimos séculos termina por oprimir a mulher, seja por acionar um processo de culpabilização do ser ou por estabelecer um rechaço social às mulheres que não executam a maternidade.

Os textos analisados demonstraram que as mulheres, ao venderem sua força de trabalho, se sentem culpadas por "abandonar os filhos" (Corrêa et al. 2007). Demonstraram também que sofrimentos psíquicos são desenvolvidos nas mulheres quando elas necessitam decidir se darão continuidade na carreira ou efetuarão uma pausa para serem mães, cientes de que essa pausa inclui responsabilidades de criação que as impedirão de dedicar-se novamente à carreira do mesmo modo que antes da maternidade. Ademais, ficou atestado também que aquelas mulheres que optam por não assumirem a função social da maternidade são "desconstruídas" enquanto mulher (Capelle \& Melo, 2010. p. 76).

A responsabilidade com o cuidado com as tarefas da casa, como limpar, cozinhar etc., também é naturalizada de tal forma que em todos os textos analisados a questão da dupla-jornada é abordada, sem, no entanto, ser problematizada. As dificuldades de inserção no mercado, de possibilidades ou dificuldades de empreender, de ascensão no trabalho, são constantemente relacionadas à necessidade de "flexibilização de horários" para a manutenção do lar e da família, ou a dupla-jornada a qual são submetidas às mulheres, pelo seu dever de chegar em casa e ainda ter de "ir para as panelas e arrumar a casa" (Reis, Medeiros, \& Valadão, 2012) (C). Contudo, é necessário dar um passo anterior e questionar: por quê?

À mulher "caberia" o papel social de cuidado do lar e dos filhos e mesmo quando possuir uma atividade remunerada, caberá a ela desempenhar essas tarefas ou designá-las à outra pessoa, ou melhor dizendo, a outra mulher, 
analisaram as relações de trabalho em uma lavanderia.

Por um lado, o papel desempenhado pelas trabalhadoras, de lavar e passar, é realizado como uma atividade remunerada para "suprir" o "dever" de outras mulheres que não conseguem desempenhar esse "papel" e possuem condições de as contratarem para realizar "os trabalhos que the correspondem enquanto mulheres" (Saffioti, 2001, p. 8). Por outro lado, ao voltar para casa, essas trabalhadoras precisam desempenhar no ambiente doméstico a mesma tarefa, agora como forma de "cumprir seu dever doméstico", exercendo um trabalho não remunerado de manutenção do lar, pois a remuneração que recebem lavando e passando não permite que terceirizem os seus afazeres domésticos a outras.

Observamos que inclusive os artigos que classificamos como críticos, por expressarem diretamente que é intenção dos autores e autoras problematizar as relações sociais postas, acabam por naturalizar o que denunciam. Outro ponto a ser destacado nessa análise é que se por um lado a manutenção do espaço privado é colocado como dever da mulher, no qual o homem desempenha apenas um papel de, no máximo, ajudar, por outro lado, o trabalho extra-casa é considerado como responsabilidade dos homens, no qual à mulher somente se insere para adquirir complementação de renda familiar, como coloca Machado, Gazola e Anez (2013): "Além disso, elas abrem empresas para ter maior flexibilidade de horário, procurando conciliar a exigência do trabalho e da família, ou para complementar a renda familiar"; ainda que hoje, conforme Taiar (2017) 40\% das famílias sejam chefiadas por mulheres.

Como colocado por Saffioti (2001), na posição de mera "ajudante", as mulheres acabam recebendo salários inferiores, ainda que desempenhem as mesmas funções. E ainda mais, a própria mulher, acreditando que o seu trabalho seja apenas uma forma de "ajuda" no provento do lar, aceita como "natural" um salário inferior. Assim, é possível perceber como a naturalização dessa relação reforça e reproduz não apenas a opressão da mulher em relação ao homem, mas "justifica" a intensificação da sua exploração.

\section{Considerações Finais}

Dada a importância da Ciência para a compreensão e o enfrentamento da realidade social, o objetivo do presente trabalho teve por indagação a seguinte questão norteadora: como os estudos hodiernos no campo das ciências administrativas que possuem como objeto de análise as mulheres em relações de trabalho explicam as desigualdades existente entre ser homem trabalhador e ser mulher trabalhadora?

Foi possível constatar que os estudos acerca da temática são recentes e escassos, contudo, a existência de artigos que se propõem a discutir a questão das particularidades sociais decorrentes das necessidades objetivas e subjetivas da mulher ingressar no mercado de trabalho pode ser considerada um avanço para a área, pois a pauta concernente ao gênero ganha relevo em um campo que por muito tempo a ignorou. Este texto, por 
exemplo, só foi possível porque os problemas sociais das mulheres não são mais ignorados enquanto um problema científico.

Entretanto, o que se apresenta como uma potencialidade para a luta das mulheres, também a limita, pois a racionalidade científica impõese sobre o real e, até mesmo aqueles artigos que se propõem críticos, acabam contribuindo, em certa medida, para naturalização da opressão, visto que, em geral, dedicam-se a descrever uma realidade por meio da representação comum da mesma, não superando a aparência fenomênica para a compreensão das relações sociais concretas.

Ratificamos: a Ciência Administrativa, no que tange ao estereótipo dual e superficial da feminilidade e masculinidade, ao invés de problematizá-lo, reforça-o. Isso foi feito tanto por meio do uso de bases teóricas que naturalizam as relações sociais, como por meio da não problematização de tais questões, de forma que acabam propagando e naturalizando características de um "ser homem" e "ser mulher", sobretudo no que se refere ao papel social atribuído às mulheres em relação à maternidade e cuidado do lar. Consequentemente, há a utilização dessas características para "justificar" o lugar social de inferioridade da mulher e dos obstáculos que elas encontram quando se deparam com outros homens no mercado de trabalho.

A natureza competitiva do mercado de trabalho não é tratada nos textos e toda a exploração da força de trabalho que atinge de forma diferente a homens e mulheres (não ignoramos isso) passa a ser tratada como meros desdobramentos de atribuições individuais, portanto, permanece o estudo das relações de trabalho abstraindo seu aspecto de processo de valorização. Não basta apenas ser mãe ou ter homens que compartilham as responsabilidades da reprodução da força de trabalho para acabar com a competição que não é da essência humana, mas da essência das trocas na sociabilidade do capital.

Destacamos que embora a atividade produtiva científica tenha sua lógica interna própria de funcionamento, esta não está apartada dos múltiplos complexos da sociabilidade humana sob o capital: os interesses contraditórios produzidos nas relações concretas conforme as condições de produção e reprodução da existência guardam correspondências com os modos de conhecer dessas condições concretas. Assim, a organização interna de um fazer científico que advoga pela primazia da razão sobre o real corresponde às necessidades do processo de valorização do capital, pois permite que o pensar determine quais os aspectos do real serão considerados como relevantes para explicar as práticas humanas, reduzindo a potencialidade do conhecimento ser um meio de produção de subjetividades que se mobilizem rumo às práticas sociais que alteram qualitativamente o real, ou, em outros termos, para revoluções na sociabilidade humana.

Vimos isso na nossa análise, pois os estudos produzidos sobre o tema "mulher" nas ciências administrativas seguem se reproduzindo conforme esquema expresso na Figura 4 Expressão das Relações de Gênero nas Mediações de Primeira e Segunda Ordem, isto é, o conhecimento produzido nas ciências administrativas se debruçam sobre a relação T-IA, em que em $T$ temos a marca naturalizada da inferioridade da mulher em relação ao homem; sendo assim, nesse debruçar-se, há novos saberes que reproduzem essas relações de exploração e opressão. 
Observamos, portanto, que a Ciência Administrativa parte de uma relação alienada do Ser Social (SS: T-P) com a Natureza (NA) e a Indústria (IA), tendo nessa particularidade um Ser Social duplamente cindido entre classe e gênero (SS: $T(H>M)-P(H>M)$ ). Fica latente que a Ciência Administrativa vem reproduzindo a naturalização do papel da mulher e das relações de classe, pois comprometida com os interesses do capital, não interessa que se alcance a essência do fenômeno, uma vez que, conforme exposto, a naturalização do papel da mulher e a manutenção de sua opressão permitem a intensificação de sua exploração e, portanto, auxilia na produção e reprodução do capital.

Por fim, revelar ou ocultar a realidade objetiva é uma arma poderosa no campo de luta de classes, pois é através do alcance da essência dos fenômenos que se cria condições de instrumentalizar-se para uma intervenção que transforme radicalmente a forma atual da sociabilidade, inclusive na e a partir da Administração (Ferraz, 2016; Ferraz \& Ferraz, 2018). Por isso, necessita-se de uma agenda de discussões, as quais busquem compreender de forma mais aprofundada os impactos da forma gnosiológica de construção do conhecimento científico para a luta das mulheres contra sua opressão e em busca da emancipação real.

Para que isso seja possível, é necessária a luta não somente pelo fim da opressão homem-mulher, mas uma luta que vislumbre a abolição da propriedade privada dos meios de produção e o estranhamento decorrente dela, uma vez que conforme exposto por Marx (2004), o trabalho estranhado gerado pela propriedade privada dos meios de produção torna o ser humano estranhado não somente da natureza e de sua própria atividade vital, mas do seu próprio ser genérico, de sua própria essência humana, tornando, pois, estranhada a relação homem-mulher.

Conforme colocado por Fortes (2015), a forma mais imediata da manifestação do estranhamento pode ser visualizada na relação entre o homem e a mulher. Portanto, a busca pela real emancipação da mulher e pela emancipação Humana implica na busca da superação da autoalienação do/no trabalho e da autoalienação entre os sexos, pois se no processo de constituição do capitalismo, uma nova forma de opressão sobre a mulher foi engendrada, sendo o fim desta passando necessariamente pelo fim daquele. E, assim, podemos afirmar que se constituem as condições concretas para efetivar a canção de Doralyce e Duffrayer: "Sou mulher, sou dona do meu corpo e da minha vontade. Fui eu que descobri Prazer e Liberdade. Sou tudo que um dia eu sonhei pra mim".

\section{Referências}

ABNT, I., \& SBM, P. R. M. (2003). Guia para a expressão da incerteza de medição. 3. Edição brasileira, Rio de Janeiro

Arksey, H., \& O'Malley, L. (2005). Scoping studies: towards a methodological framework. International journal of social research methodology, 8(1), 19-32

Caminhas, L. R. P. (2019). Imagens de violência de gênero em telenovelas brasileiras. Revista Estudos Feministas, 27. 
Cappelle, M. C. A., \& Melo, M. C. O. L. (2010). Mulheres policiais, relações de poder e de gênero na polícia militar de Minas Gerais. RAM. Revista de Administração Mackenzie, 11(3), 71-99

Cappelle, M. C. A., Brito, M. J., Melo, M. C. O. L., \& Vasconcelos, K. A. (2007). A produção científica sobre gênero nas organizações: uma meta-análise. REAd. Revista Eletrônica de Administração, 13(3), 502-528.

Chasin, J. (2009). Marx: estatuto ontológico e resolução metodológica. São Paulo: Boitempo.

Corrêa, A. M. H., Gontijo, M. C. L., Assis, L. B., Carrieri, A. P., \& Melo, M. C. O. L. (2007). Soldadinhos-de-chumbo e bonecas: representações sociais do masculino e feminino em jornais de empresas. Revista de Administração Contemporânea, 11(2), 191-211

Costa, G. M. (2009). Contribuição da análise imanente à pesquisa de textos. Revista Eletrônica Arma da Crítica, 1, 24-33.

Cotrim, A. (2012) Trabalho produtivo em Karl Marx: velhas e novas questões. São Paulo: Alameda.

Cotrim, A. A., \& Cotrim, V. A. (2020). Hegel e Marx sobre o patriarcado: naturalização e ruptura. Revista Cerrados, 29(52), 120-151.

Doralyce, D. S. (2008) Mulheres versão 2018. Recuperado em 20 outubro, 2020, de https://www.youtube.com/watch?v=kInIPtOaqSs

Ferraz, D. L. (2016). A administração de recursos humanos como conhecimento que constitui uma consciência de classe para o capital. Revista Brasileira de Administração Política, 9(2), 65-87.

Ferraz, D. L. S., Chaves, R. H. S., \& Ferraz, J. M. (2018). Para além da Epistemologia: reflexões necessárias para o desenvolvimento do conhecimento. REAd. Revista Eletrônica de Administração, 24(2), 1-30.

Ferraz, J. M., \& Ferraz, D. L. S. (2018). O materialismo histórico e Dialético: porque ser contra-hegemônico (pode) não é ser contra o capital. In E. Paço-Cunha \& D. L. S. Ferraz (Orgs.). Crítica Marxista da Administração. Rio de Janeiro: Rizoma.

Fortes, R. V. (2015). O estranhamento da mulher na "Ontologia" de Lukács. In P. Tortiglia, R. Lara, R. G. Müller \& V. Ortigara (Orgs.). Ontologia e crítica do tempo presente. Florianópolis: Editora em Debate.

Galvão, K. D. S., Silva Neto, O. S., Santos, J. F. D., \& Raboni, P. L. (2016). Análise dos modelos de precificação de ativos sob uma abordagem epistêmica do positivismo/ pós-positivismo e do construtivismo. Cadernos EBAPE. BR, 14(1), 228-242.

Graneheim, U. H., \& Lundman, B. (2004). Qualitative content analysis in nursing research: concepts, procedures and measures to achieve trustworthiness. Nursey Education Today, 24, 105-112.

Grzybovski, D., Boscarin, R., \& Migott, A. M. B. (2002). Estilo feminino de gestão em empresas familiares gaúchas. Revista de Administração Contemporânea, 6(2), 185-207.

Lukács, G. (2010). Prolegômenos para uma ontologia do ser social: questões de princípios para uma ontologia tornada hoje possível. (L. Luft \& R. Nascimento, Trad.). São Paulo: Boitempo. 
Macedo, R. M. (2016) Espelho mágico: produção e recepção de imagens de empregadas domésticas em uma telenovela brasileira. Cad. Pagu, 48, e164817.

Machado, H. P. V., Gazola, S., \& Anez, M. E. M. (2013). Criação de empresas por mulheres: um estudo com empreendedoras em Natal/RN. Revista de Administração Mackenzie, 14(5), 177-200.

Marx, K. \& Engels, F. (2007). A Ideologia Alemã (J. Ranieri, Trad.). São Paulo: Boitempo Editorial.

Marx, K. (2004). Manuscritos econômico-filosóficos. (R. Enderle, Trad.). São Paulo: Boitempo Editorial.

Marx, K. (2013). O Capital - Livro 1. (R. Enderle, Trad.). São Paulo: Boitempo Editorial. Mészáros, I. (2006). A teoria da alienação em Marx. São Paulo: Boitempo Editorial. Montenegro, A. (1981). Ser ou não ser feminista. Recife: Ed. Guararapes.

Nascimento, M. C.R., Oliveira, J. S., Teixeira, J. C., \& Carrieri, A. P. (2015). Com que cor eu vou pro shopping que você me convidou? Revista de Administração Contemporânea, 19(3), Edição especial, 245-268.

Oliveira, S. C. M., Barbosa, E. S., Rezende, R. P. A., \& Albuquerque, S. L. (2013). Bibliometria em artigos de contabilidade aplicada ao setor público. Anais do Congresso Brasileiro de Custos, São Leopoldo, RS, Brasil, 20.

Paço-Cunha, E. (2018). Ontogênese e formas particulares da função de direção: introdução aos fundamentos históricos para a crítica Marxista da administração. In E. Paço-Cunha \& D. L. S Ferraz (Orgs.). Crítica Marxista da Administração. Rio de Janeiro: Rizoma.

Paço-Cunha, E. P., \& Ferraz, D. L. D. S. (2015). Marxismo, estudos organizacionais e a luta contra o irracionalismo. Organizações \& Sociedade, 22(73), 193-198.

Rosa, A. R., Medeiros, C. R. D. O., \& Valadão Júnior, V. M. (2012). Sob as sombras do discurso colonial: subalternidade e configurações de gênero em uma lavanderia do interior de Minas Gerais. Cadernos Ebape. BR, 10, 393-410

Saffioti, H. I. B. (2001). O poder do macho. 11.Ed. São Paulo: Editora Moderna.

Silva, E. R. (2008). Feminismo radical - Pensamento e movimento. Travessias, 2(3).

Souza, E. M. D., Corvino, M. D. M. F., \& Lopes, B. C. (2013). Uma análise dos estudos sobre o feminino e as mulheres na área de administração: a produção científica brasileira entre 2000 a 2010. Organizações \& Sociedade, 20(67), 603-621

Taiar, E. (2017). Número de lares chefiados por mulheres sobe de 23\% para 40\% em 20 anos. Valor Econômico. Recuperado em 10 novembro, 2017, de http://www. valor.com.br/brasil/4889492/numero-de-lares-chefiados-por-mulheres-sobe-de-23para-40-em-20-anos

Toledo, C. (2003). Mulheres: o gênero nos une, a classe nos divide. 2.Ed. São Paulo: José Luís e Rosa Sundermann.

UN Women (2020). The world for women and girls. Annual report 2019-2020. New York. Recuperado em 15 outubro, 2020, de unwomen.org/en/digital-library/ annualreport

Vaisman, E. (2006). A usina onto-societária do pensamento. Verinotio-Revista on-line de Filosofia e Ciências Humanas, 4, 24-24. 